\title{
Iron metabolism in solid-organ transplantation: how far are we from solving the mystery?
}

\author{
Jolanta Małyszko', Nomy Levin-Iaina², Michał Myśliwiec', \\ Piotr Przybyłowski ${ }^{3}$, Magdalena Durlik ${ }^{4}$ \\ 1 Department of Nephrology and Transplantology, Medical University of Bialystok, Białystok, Poland \\ 2 Nephrology and Hypertension Institute, Chaim Sheba Medical Center, Tel-Hashomer Hospital, Ramat Aviv, Israel \\ 3 Department of Cardiovascular Surgery and Transplantology, Jagiellonian University Medical College, Kraków, Poland \\ 4 Department of Transplantation and Nephrology, Medical University of Warsaw, Warszawa, Poland
}

\section{KEY WORDS}

ferritin, heart, hepcidin, iron metabolism, liver transplantation
Correspondence to:

Prof. Jolanta Małyszko, MD, PhD, Klinika Nefrologii i Transplantologii, Uniwersytet Medyczny, ul. Żurawia 14 15-540 Białystok, Poland, phone: +48-85-740-94-64, fax: +48-85-743-45-86, e-mail: jolmal@poczta.onet.pl Received: September 10, 2012. Revision accepted: October 4, 2012. Conflict of interest: none declared. Pol Arch Med Wewn. 2012; 122 (10): 504-511

Copyright by Medycyna Praktyczna, Kraków 2012

\section{ABSTRACT}

Iron is the most abundant transition metal in the human body and an essential element required for growth and survival. Our understanding of the molecular control of iron metabolism has increased dramatically over the past 10 years due to the discovery of hepcidin, which regulates the uptake of dietary iron and its mobilization from macrophages and hepatic stores. Although general practitioners and internists encounter iron deficiency and anemia in their everyday practice, little is known about iron metabolism in patients after solid-organ transplantation. The aim of this review was to summarize the current knowledge on iron metabolism in kidney, heart, and liver transplant recipients. Iron deficiency and/or anemia, as well as iron overload, are frequently observed but the precise mechanism of these disturbances have not been fully elucidated. Iron deficiency is more prevalent in kidney and heart transplant patients, while iron overload in liver transplant recipients. Secondary and potentially reversible causes of these disturbances should be considered such as inflammation, graft failure, and type of immunosuppression. Iron status check-up should be a part of long term follow-up because disturbances in iron metabolism are a possible risk factor of infections and mortality in solid transplant recipients. Internists and general practitioners are often the first doctors to take care of organ transplant recipients (before they will present at outpatient transplant clinics or hospital transplant units); therefore, knowledge about the disturbances in iron metabolism in this specific population would be useful for better diagnosis and treatment both before and after transplantation.

Introduction Iron is the most abundant transition metal in the human body and an essential element for growth and survival of any form of life. On the other hand, it is toxic to the cells due to its ability to catalyze free radical generation. The absence of a physiological excretion mechanism requires iron homeostasis to be regulated by iron absorption from the intestine and the recycling of iron from senescent red blood cells. ${ }^{1-4}$ Thus, the regulation of iron metabolism involves the interaction of a number of specific proteins as well as the interplay between iron absorption and loss. ${ }^{5}$

Critical proteins in iron homeostasis The critical proteins involved in iron homeostasis are transferrin (measured in the laboratory as the total iron binding capacity [TIBC]), transferrin receptor and ferritin (the cellular storage protein for iron but at the same time an acute-phase reactant). ${ }^{2}$ The newest proteins include ${ }^{5}$ an intracellular reporter of iron status, the iron responsive element-binding protein (also called iron regulatory protein [IRP] or factor); hemochromatosis gene (HFE; mutations of which are responsible for hereditary hemochromatosis); divalent metal transporter (also known as DMT1, Nramp2, DCT1, solute carrier family 11, member 2); duodenal iron transporter, a stimulator of iron transport, ferroportin; and hephaestin (iron export proteins). Moreover, they include hepcidin, a possible negative regulator of intestinal iron absorption as well as macrophage iron release ${ }^{6}$; hemojuvelin (HJV), cofactor for hepcidin ${ }^{7}$; 
bone morphogenetic protein 6 (BMP6), a cytokine produced in iron overload and responsible for the main pathway of hepcidin activation ${ }^{8}$; and finally matriptase-2 (TMPRSS6, type II transmembrane serine protease expressed primarily in the liver), which cleaves HJV on the plasma membrane, resulting in hepcidin inhibition by blocking the BMP/HJV-activating pathway. In mice, defects in the TMPRSS6 gene encoding matriptase- 2 result in high hepcidin expression and cause severe microcytic anemia. ${ }^{9}$ Similarly, mutations in the human TMPRSS6 gene have been identified in patients with iron-refractory iron-deficiency anemia (IRIDA). ${ }^{10}$ IRIDA is associated with severe microcytosis, while the anemia of chronic disease is typically normocytic. In IRIDA, high serum ferritin and low transferrin saturation (TSAT), even after parenteral iron treatment, are typical findings.

The sensors of erythropoietic state are 3 proteins: erythropoietin, growth differentiation factor 15 (GDF15), and twisted gastrulation. GDF15 is a family member of the transforming growth factor- $\beta$ superfamily and is secreted by hemoglobinized erythroblasts during the final stages of erythropoiesis. Elevated serum GDF15 correlates with decreased hepcidin and increased iron absorption. ${ }^{11,12}$ Interestingly, a more recent study has shown that GDF15 expression is negatively regulated by the intracellular iron levels independent of hypoxia-inducible factor and IRP activation. ${ }^{13}$

Iron distribution in the body The total iron content of the normal human body is about 3 to $4 \mathrm{~g}$, most of it being associated with hemoglobin in circulating erythrocytes (approximately $2.5 \mathrm{~g}$ ), iron-containing proteins such as myoglobin, cytochromes, catalase (about $400 \mathrm{mg}$ ), bound to transferrin (3-7 mg). ${ }^{1}$ The remainder is storage iron in the form of ferritin or hemosiderin. Daily iron requirement for erythropoiesis is from about 20 to $25 \mathrm{mg}$. It comes largely from macrophages which have phagocytosed senescent erythrocytes. ${ }^{14}$ This process makes it possible to recycle approximately from 25 to $30 \mathrm{mg}$ of iron per day, which corresponds to the daily requirement of iron for erythropoiesis. In men, the storage pool of iron is about $1 \mathrm{~g}$ (mainly in the liver, spleen, and bone marrow). Due to iron losses with blood during menses, deliveries, pregnancies, etc., adult women have lower iron storage.

Dietary sources of iron A typical Western diet contains about $15 \mathrm{mg}$ of iron, some of which is heme iron. About $30 \%$ of this heme iron is promptly absorbed, ${ }^{15,16}$ while the remaining iron, accounting for almost all iron in non-Western diet, is poorly absorbed. Less than $10 \%$ is being taken into the mucosal cells. Diet rich in heme iron, i.e., in fish, poultry, and meat contains more bioavailable iron than the vegetarian diet (30\% vs. $10 \%)$. Nonanimal sources of iron, i.e., cereals, bread, fruit, or vegetables are absorbed better in the presence of ascorbic acid, whereas teas (rich in tannates), bran foods (rich in phosphates and phytates) inhibit iron absorption by forming complexes with iron. The intestinal absorption of iron ensured by the mature enterocytes at the top of duodenal villi is from about 1 to $2 \mathrm{mg}$ per day (i.e., $30 \%$ of $1-2 \mathrm{mg}$ of heme iron in the Western diet and about $10 \%$ of $10-15 \mathrm{mg}$ of nonheme iron). It makes it possible to compensate for losses, resulting mainly form the exfoliation of the epithelial cells. Thus, iron homeostasis is regulated strictly at the level of intestinal absorption.

Red cell production Production of red blood cells is an active process leading to daily production of 200 billion new mature erythrocytes in order to compensate for the destruction of senescent red blood cells by macrophages. Erythropoiesis is controlled mainly by erythropoietin and availability of iron. Normally, three quarters of the body's iron is present in circulating red blood cells, and the remaining one quarter is stored mainly in the liver and bone marrow.

Normally, one-third of transferrin is saturated with iron (i.e., Fe/TIBC equals 33\%). ${ }^{15,17}$ TSAT is decreased when iron supply to the plasma from macrophages and other storage sites is reduced, i.e., iron-deficiency anemia, anemia of chronic inflammation (disease), and, in some cases, of ferroportin mutations. On the other hand, TSAT is increased when iron supply exceeds its demand, i.e., aplastic, sideroblastic anemia, hemochromatosis, liver disease, and other forms of ineffective erythropoiesis. Transferrin receptors are present in hepatocytes and epithelial cells of the small intestine, including duodenal crypts. ${ }^{18}$ They probably contribute to the body's iron sensing. ${ }^{19-21}$ Each receptor can bind 2 transferrin molecules, and, after their endocytosis, iron is offloaded $\left(4 \mathrm{Fe}^{+}\right.$atoms) in acidified vacuoles. Then, the complex of the apotransferrin and transferrin receptor is recycled on the cell surface and released into circulation. ${ }^{22}$ Ferritin present in virtually all cells, including hepatocytes, is the cellular storage protein for iron and, at the same time, an acute-phase reactant. The serum level of ferritin generally reflects the overall iron storage, with $1 \mathrm{ng}$ of ferritin per $\mathrm{ml}$ indicating $10 \mathrm{mg}$ of total iron stores. ${ }^{23}$ The intracellular correlate of transferrin is ferritin. Bone marrow and liver biopsies and/or hepatic magnetic resonance imaging are more specific ways to measure tissue iron stores; however, serum iron indices are less invasive, less expensive, and more clinically available. From the clinical perspective, on one side, iron-deficiency anemia is the most common anemia worldwide; on the other side, primary (hemochromatosis) or secondary defects in the iron regulation system leading to iron overload are also present in human pathology. Most of the conditions associated with secondary iron overload are characterized also by anemia. The source of iron may be parenteral (transfusions, iron compounds), from increased oral intake (diet, iron compounds, or enhanced 
iron absorption due to ineffective erythropoiesis or liver disease). Sometimes more than $1 \mathrm{fac}-$ tor can be present in the same patient. It is often crucial to diagnose the cause of the disturbances in iron metabolism to timely introduce proper treatment, including organ transplantation in certain cases.

Iron deficiency Iron deficiency may develop when unmet increased iron requirement or inadequate supply, or both are present. Clinical presentation of iron deficiency may vary from a casual finding only of laboratory abnormalities on routine screening in the absence of clinical symptoms to profound, clinically relevant iron-deficiency anemia with the so called pica. Typically, we could classify iron deficiency into 3 progressive stages ${ }^{24}: 1$ ) storage-iron depletion characterized only by a decrease in serum ferritin below $12 \mathrm{mg} / \mathrm{ml}$ with normal hematological parameters (hemoglobin, red cell indices); 2) iron deficiency without anemia characterized by normal hemoglobin levels but with biochemical and hematological sings such as a decrease in TSAT, increase in circulating transferrin receptor, rise in erythrocyte zinc protoporphyrin, rise in percent of hypochromic erythrocytes, and abnormally low reticulocyte hemoglobin content; 3) iron-deficiency anemia characterized by classic biochemical signs of iron deficiency with hematological changes reflecting iron-deficient erythropoiesis with anemia, decreased mean corpuscular volume, mean corpuscular hemoglobin, reticulocyte hemoglobin content, and increased red distribution width.

Iron deficiency in chronic kidney disease In chronic kidney disease (CKD), an important issue is the diagnosis of iron deficiency due to the fact that the laboratory criteria are markedly different from those in persons with relatively normal renal function. Absolute iron deficiency is likely to be present in advanced CKD when TSAT falls below $20 \%$ and ferritin below $100 \mathrm{ng} / \mathrm{ml} .{ }^{25}$ In normal subjects, these values of ferritin are within the normal range. These discrepancies in serum ferritin between normal subjects and CKD patients are partly due to the fact that ferritin is an acute-phase reactant and CKD is a subclinical inflammatory state. However, a functional iron deficiency may also exist among patients with CKD. This is characterized by the presence of adequate iron stores as defined by the conventional criteria, but with the inability to sufficiently mobilize iron to adequately support erythropoiesis with the administration of erythropoietin. An inadequate amount of iron is released from the liver and other storage sites. In such patients, the serum ferritin level is either normal or elevated usually between 100 and $800 \mathrm{ng} / \mathrm{ml}$, with TSAT typically about $\leq 20 \%$.

Iron repletion and overload Iron repleted state is characterized by an increased production of ferritin to permit adequate storage along with decreased production of the transferrin receptor to minimize further iron entry into the cell. To establish the presence of iron overload (increased body iron burden), serum iron measurement, various radiological tests, liver biopsy, and the assessment of the response to phlebotomy or chelation therapy should be performed. ${ }^{26}$ In severe iron overload states, TSAT can approach $100 \%$ and the unsaturated iron-binding capacity can approach 0 . A fasting TSAT of $60 \%$ or higher in men and of $50 \%$ or higher in women has accuracy of over $90 \%$ in detecting patients with the homozygous form of hereditary hemochromatosis in whom clinical symptoms or documented iron overload is present. ${ }^{27-29}$ Serum ferritin concentration above $300 \mathrm{ng} / \mathrm{ml}$ in men and $200 \mathrm{ng} / \mathrm{ml}$ in women are suggestive of iron overload, provided that acute inflammation is not present. ${ }^{27}$

Iron and infections The growth and metabolism of many microorganisms is exquisitely iron-sensitive. ${ }^{30}$ Readily available serum iron is metabolized by pathogen iron and heme enzyme systems, facilitating increased bacterial and fungal growth, which may overwhelm other host defenses and result in clinical infection. Bacteria require iron for the production of the superoxide dysmutase that protects them from host oxygen radicals. ${ }^{31,32}$ However, iron concentration in the environment or in the host is too low to sustain the optimal conditions for invading microorganism. Both bacteria and the host developed mechanisms to tackle with this problem. Bacteria developed siderophores (high-affinity iron-binding molecules) retrieving iron from transferrin or lactoferrin of the host. The host also developed defense mechanisms such as increased production of iron-binding proteins (i.e., transferrin and ferritin), decrease in dietary iron absorption, and release of apolactoferrin from neutrophils to sequester the iron at the site of invading microorganism. Hepcidin, by inducing sequestration of iron in macrophages, deprives bacteria of this element. Blood and intracellular bacteria may weaken and biofilms may not develop. ${ }^{33}$ Defensins are antimicrobial peptides produced by the cells of epithelial lining. ${ }^{34}$ Hepcidin is an acute-phase protein that kills microbes both on contact, like defensins, ${ }^{35}$ and by causing hypoferremia. ${ }^{36}$ Hence, during inflammation, infection, ${ }^{37}$ and possibly also in cancer, ${ }^{38}$ elevated hepcidin results in decreased iron release from enterocytes, hepatocytes, and macrophages. It leads to the fall in serum iron and diminished availability of iron for bacteria and tumor cells. Hypoferremia (or stress hypoferremia) is thus believed to contribute to host defense against invading pathogens and tumor cells and reverses this pathogenic effect and restores the antimicrobial properties of host serum. ${ }^{39,40}$ This decrease in iron availability, or iron-withholding, may serve as a defense mechanism after infection or other stressful event. ${ }^{41}$ 
Dark side of iron in transplantation The exact role of iron in the clinical setting of infection remains unclear, although its role in the pathogenesis of infection has been well documented. Infection is one of the major cause of morbidity and mortality in solid-organ transplantation. ${ }^{42-44}$ Iron is not only a critical element for microorganisms, but it also enhances microbial virulence and impairs host responses to invaders. ${ }^{45-49}$ Intracellular iron affects respiratory burst activity, and it is necessary for the generation of microbicidal effector molecules such as reactive oxygen and nitrogen intermediates. ${ }^{50,51}$ In addition, iron negatively affects neutrophil phagocytic function. ${ }^{52}$ On the other hand, iron overload has a negative effect on T-cell responses with increased $\mathrm{CD} 8^{+}$by enhancing suppression of T-cell numbers and activities, decreasing the proliferative capacity of $\mathrm{T}$ cells, impairing the synthesis of cytotoxic T cells and immunoglobulin secretion at the expense of reduced $\mathrm{CD} 4^{+}$cell counts and reduced mitogenic response to standard antigens and impaired hypersensitivity responses, as presented by Singh and Sun. ${ }^{53}$ T-cell responses are vital for protection against viral and fungal infections.

Ashrafian ${ }^{54}$ presented a list of genera of infectious-disease organisms requiring iron for growth and whose virulence was enhanced by iron excess. It should also be stressed that iron overload favors T-helper 2 (Th-2)-dominant response, which is associated with progressive infection and worsening of the clinical course of the disease. ${ }^{50}$ Interestingly, immunocompromised patients (i.e., diabetic, with end-stage kidney disease, liver impairment, human immunodeficiency virus [HIV], cancer), particularly those with iron overload, have a striking predisposition to become infected by other aggressive bacteria such as Listeria monocytogenes, Klebsiella spp., Yersinia spp., and Vibrio vulnificus. ${ }^{54}$ The last one is mainly found in fish and filter feeders such as oysters and clams (up to $50 \%$ culture positive) and crabs (up to $11 \%$ culture positive). ${ }^{55,56}$ Type of infections may vary from wound infections to septic shock ${ }^{57,58}$; therefore, seafood should not be recommended to solid-organ transplant recipients. It has been reported that heme is a critical nutrient source for Staphylococcus aureus and contributes to its spread and virulence. ${ }^{59,60}$ Iron is also a vital growth factor for Aspergillus, which access transferrin-bound iron by siderophore. ${ }^{61}$ Similarly, Rhizopus spp. use siderophore to acquire iron. ${ }^{62}$ Cryptococcus neoformans does not produce siderophores and uses other mechanisms for iron acquisition, including reduction of ferric iron. ${ }^{63}$ Although viruses do not require iron, infected host cells need this element for the synthesis of viral particles. Iron homeostasis is also important in the pathogenesis of human viral infections, such as cytomegalovirus (CMV), hepatitis $C$, herpes simplex virus, and HIV. ${ }^{64-67} \mathrm{CMV}$ infection is linked to endothelial cell activation, and iron promotes these changes. ${ }^{67}$ Labile iron facilitates human CMV-induced host cell enlargement and accounts for host cellular dysfunction in the early course of CMV infection. ${ }^{64} \mathrm{~A}$ lower incidence of CMV infection is found in patients treated with the mammalian target of rapamycin (mTOR) ${ }^{68,69}$; however, whether it might be related to the significant reduction in iron by sirolimus remains to be proved. It has also been reported that iron plays a role in the pathogenesis of herpes simplex virus, ${ }^{70}$ and iron overload modulates the clinical course of $\mathrm{HCV}$ infection by affecting Th-1/Th- 2 responses and is predictor of unfavorable response to treatment with interferon- $\alpha .{ }^{71,72} \mathrm{~A}$ better understanding of iron metabolism and its relationship to infections, particularly those very uncommon in healthy volunteers and often fatal in solid-organ transplant recipients, could help guide future infection prognosis, prevention, and management in this high-risk population.

Iron metabolism in kidney allograft recipients $\mathrm{Re}-$ cently, understanding of the molecular control of iron metabolism has increased dramatically due to the discovery of hepcidin, a peptide hormone produced in the liver with primary responsibility for modulating iron availability to meet iron needs. ${ }^{6}$ The kidney is also involved in iron metabolism. There is abundant expression of Nramp2 in the proximal tubule and collecting ducts of the kidney. ${ }^{73}$ This raises the possibility that there is an iron excretory pathway in the kidney, counteracted by its constitutive reabsorption. On the other hand, Nramp1 expressed in the neutrophil granules, known to harbor neutrophil gelatinase-associated lipocalin (NGAL) and lactoferrin, is believed to reduce the availability of iron in the phagocytic vacuoles by pumping iron into the cytosol. As described previously, NGAL is also associated with iron metabolism and inflammation. ${ }^{74,75}$ Despite the supposition that renal transplant recipients receive more care from nephrologists, iron status is evaluated and appropriate epoetin therapy administered only in $25 \%$ of transplant patients. ${ }^{76,77}$

Iron status and iron deficiency have not been extensively studied in kidney allograft recipients. It has become clear that effective erythropoiesis due to recovery of renal function depletes iron stores. Major contributors to iron deficiency in kidney allograft recipients are inadequate iron stores at the time of transplantation (while on renal replacement therapy or at CKD stage 5 awaiting preemptive transplantation), blood losses due to surgery, and iatrogenic blood losses due to posttransplant phlebotomy.

Moreover, in parallel with the recovery of renal function after successful transplantation, effective erythropoiesis depletes iron stores according to the study by Moore et al. ${ }^{78}$ who reported that $60 \%$ of kidney allograft recipients without iron deficiency at the time of transplantation become iron-deficient 6 months after transplantation. Lorenz et al. ${ }^{79}$ reported that the prevalence of iron deficiency, defined as the percent of hypochromic blood cells of $2.5 \%$ or higher, was $20 \%$. Iron 
status is not routinely assessed in kidney allograft recipients. According to Shibagaki and Shetty, ${ }^{80}$ only $36 \%$ of anemic kidney transplant recipients had their iron status assessed - iron deficiency was diagnosed in half of these patients. Moreover, Shah et al. ${ }^{81}$ reported that despite the high prevalence of anemia reaching $45.6 \%$ in 1511 renal transplant recipients, only $46 \%$ had their ferritin measured. Recently, Zheng et al. ${ }^{82}$ tried to answer the question about blood and iron losses over the first 12 weeks after transplantation. They quantified the magnitude and sources of blood and iron losses in the early posttransplant period. Standard phlebotomy for the assessment of graft function and immunosuppressive drug levels largely contributed to blood loss within the first weeks after transplantation. Moreover, to increase hemoglobin from the target level of 10 to $12 \mathrm{~g} / \mathrm{dl}$ in CKD patients to the normal range observed in patients with good graft function, a substantial additional amount of almost $1 \mathrm{~g}$ iron is required. ${ }^{82}$ They even suggested intravenous iron during hospitalization after transplantation to replete iron stores and minimize iron deficit. As reported by Jimeno et al., ${ }^{83}$ iron deficiency was present in $62.4 \%$ of long-term kidney transplant recipients without anemia. In our previous study, complete iron status was assessed only in 51 prevalent kidney transplant recipients (26\%) based on the data available in medical records from routine periodical check-ups of the transplanted cohort. ${ }^{84}$ Absolute iron deficiency was found in $8 \%$ of kidney transplant recipients and functional iron deficiency in $6 \%$. Therefore, iron supplementation should be considered in kidney allograft recipients more often. In a recent study by Mudge et al., ${ }^{85} 104$ kidney transplant recipients were prospectively randomized to a single dose of intravenous iron polymaltose or oral ferrous sulfate. They found similar secondary outcomes profile, i.e., infections, acute rejection, blood transfusions, and severe gastrointestinal side effects, between the intravenous iron and the oral iron groups. They concluded that a single dose of intravenous iron did not result in a more rapid resolution of anemia compared with oral iron. Both iron preparations were safe and effective in the management of posttransplant anemia. However, it seems that oral iron would be easier to administer from the logistic and economic perspective.

Labile plasma iron (LPI) is a heterogeneous fraction composed of iron bound to serum albumin, citrate, and other undefined, negatively charged ligands, called nontransferrin bound iron (NTBI). ${ }^{86}$ It is associated with the formation of reactive oxygen species, which is implicated in the pathogenesis of myocardial infarction and bacterial infection. ${ }^{87,88}$ The term LPI is an operational definition for NTBI and denotes all iron in the plasma that is loosely bound and hence may have redox-active potential. As shown previously, the present fluorescent assay based on the quenching of fluorescein apotransferrin by LPI was sensitive and reproducible. ${ }^{89}$ The design of the assay ensures that iron bound to low-molecular-weight molecules that may serve as LPI ligands, such as albumin, citrate, and adenosine triphosphate is largely mobilized by oxalate. In our study, we found that LPI of 0.6 units or higher was present in $19 \%$, whereas LPI of 0.4 units or higher in 42 kidney allograft recipients (36\%), and was related to ferritin. ${ }^{90}$ LPI was not observed in healthy individuals. Very high ferritin together with high NTBI were found in patients undergoing multiple transfusions before and/or after transplantation.

Iron metabolism in heart transplant recipients The role of iron deficiency in the complex interplay of heart failure (HF), anemia, and renal dysfunction has been less well examined. Iron deficiency was found in $32 \%$ and $57 \%$ of nonanemic and anemic patients with systolic HF, respectively, in 1 large observational study. ${ }^{91}$ Parikh et al. ${ }^{92}$ reported the prevalence of $61 \%$ among community-dwelling HF patients, whereas Okonko et al., ${ }^{93}$ who based the definition of iron deficiency on TSAT alone, reported $43 \%$ of the patients to have iron deficiency, and $100 \%$ of those with the New York Heart Association class IV. The presence of concomitant chronic renal dysfunction - an inflammatory condition with increased levels of circulating cytokines - also increases the likelihood of hepcidin-induced iron deficiency. ${ }^{94}$ Jankowska et al., ${ }^{95}$ in the largest prospective study investigating iron deficiency in HF, observed that increasing severity of HF symptoms was associated with higher likelihood of iron deficiency.

There are virtually no data on iron metabolism in heart transplant recipients (OHT). In our study, all iron parameters were available for $50 \%$ of the patients, and anemic patients had a tendency for lower TSAT compared with nonanemic ones. ${ }^{84}$ Patients treated with mTOR inhibitors (both kidney recipients and OHT) had lower estimated glomerular filtration rate (eGFR), higher high-sensitivity C-reactive protein (hs-CRP), interleukin 6 (IL-6), and soluble transferrin receptor. ${ }^{96}$ Patients given mycophenolate mofetil / mycophenolic acid had lower serum iron, lower eGFR, but similar IL-6, hs-CRP, and hepcidin. It might suggest that subclinical inflammatory state together with impaired kidney function are responsible for anemia in transplant recipients, particularly those treated with mTOR inhibitors. In a recent study, Przybyłowski et al. ${ }^{97}$ reported that the prevalence of anemia, according to the World Health Organization, was $51 \%$ in OHT treated with mTOR, while in the remaining OHT it was $30 \%$. Functional iron deficiency defined as ferritin levels over $200 \mathrm{ng} / \mathrm{ml}$ with TSAT below 20\% was present in $80 \%$ of mTOR-treated patients. However, the precise mechanism of mTOR--inhibitor-induced anemia has not been clarified so far. Maiorano et al..$^{98}$ suggested that sirolimus interferes directly with iron metabolism and that sirolimus-induced anemia does not present the features of 
inflammation-related anemia. McDonald et al. ${ }^{99}$ reported that in OHT the prevalence of anemia increased from $71 \%$ to $75 \%$ after sirolimus initiation. Anemic patients were more likely to be male with worse renal function. A drop in hemoglobin by $20 \mathrm{~g} / \mathrm{l}$ or more was observed in $25 \%$ of the overall cohort. Patients investigated for anemia had low hemoglobin, normal mean corpuscular volume, low serum iron levels, and low TSAT. Muller et al. ${ }^{100}$ reported $72 \%$ anemic patients in the group of 60 outpatients followed for 5 years after heart transplantation. Deficiency of iron, vitamin $B_{12}$, or folic acid was not observed. We also studied iron parameters in $\mathrm{OHT}$ and found that they were available in $62 \%$ of the patients. ${ }^{84} \mathrm{Ab}$ solute iron deficiency was found in $35 \%$ and functional iron deficiency in $4 \%$ of OHT. Functional iron deficiency was associated with significantly higher serum ferritin and TSAT. In addition, OHT with absolute iron deficiency had lower erythrocyte blood count, were younger, with shorter time after transplantation; however, hemoglobin did not differ significantly. We also assessed the prevalence of NTBI in OHT and found that in all studied patients except 4 NTBI was negative and equal to $0 .{ }^{101}$ Because in OHT blood transfusions are the ultima refugium in order not to increase the risk of humoral rejection, probably due to such management NTBI was negative in the study population. We concluded that there was no evidence of reactive oxygen species-induced tissue damage in OHT due to either iron overload (oversupplementation) or excessive blood transfusion. Przybyłowski et al. ${ }^{102}$ also studied some markers of iron status and found that HJV strongly correlated with kidney function and inflammation, while hepcidin was also elevated in OHT. ${ }^{103}$

Iron metabolism in liver transplantation As reported previously, renal impairment was common in post-liver transplantation with the prevalence of $25 \%$ in patients surviving 10 years following the procedure. ${ }^{104}$ However, the prevalence of CKD (eGFR $<60 \mathrm{ml} / \mathrm{min}$ ) after orthotopic liver transplantation is not precisely known, and several factors may contribute including hypersplenism, renal failure, inflammatory syndrome, and de novo or recurrent malignancies. ${ }^{105-108}$ Pretransplant kidney function is also an important predictor of outcome. ${ }^{109}$ Iron metabolism in liver transplant patients is still a mystery. Only a few available papers deal with iron status in this population. The liver is the key organ in iron metabolism as the site of hepcidin synthesis; it is also the primary iron storage organ. The most important part of the processes related to transcriptional control of hepcidin biosynthesis occurs in the hepatocyte plasma membrane. Almost all the above key factors in iron metabolism are synthesized in the liver. We just briefly describe their role to better understand iron disturbances in liver pathology. The BMP/HJV pathway, ${ }^{110-112}$ whose central component is the glycosylphosphatidylinositol
(GPI)-anchored protein HJV encoded by the Hfe2 gene, ${ }^{113}$ is the key signaling pathway, which regulates Hamp gene expression in response to liver iron stores. At first, the transcriptional activation of $B M P 6$ expression ${ }^{114}$ initiates the signaling cascade, which ultimately leads to hepcidin secretion by hepatocytes. BMP6, produced probably by nonparenchymal liver cells, ${ }^{115}$ subsequently binds to $\mathrm{HJV}$ at the extracellular side of the hepatocyte membrane, resulting in effective interaction of $B M P 6$ with its transmembrane receptors. HJV thus serves as a $B M P 6$ coreceptor. Therefore, the BMP/HJV pathway is now regarded as the main pathway controlling Hamp expression in response to liver iron levels. In addition, matriptase-2, by cleaving HJV, has been proposed to remove the crucial constituent of the BMP/HJV pathway from the membrane, and thus decrease Hamp expression.

Liver cirrhosis is associated with a variable degree of iron deposits, often reaching the levels observed in primary iron overload, ${ }^{116,117}$ although end-stage liver disease due to hemochromatosis is a relatively rare indication for transplantation. As reported by Singh et al., ${ }^{118}$ a substantial proportion of patients after liver transplantation had liver iron contents exceeding the normal limits. Iron overload is associated with fatal cardiovascular events following liver transplantation. ${ }^{119}$ Myocardial iron deposits were observed postmortem in patients who died of cardiac events after transplantation. O'Glasser et al. ${ }^{119}$ reported that out of 856 patients evaluated for liver transplantation, $34 \%$ had TSAT of $50 \%$ or more and ferritin of $250 \mathrm{ng} / \mathrm{ml}$ and higher. Patients with iron overload had more advanced liver disease than those with normal iron indices, and in some patients iron cardiac deposits were found on endomyocardial biopsy. They concluded that non-HFE-related cardiac iron overload can occur in advanced liver disease. Since patients with hereditary hemochromatosis are known to have an increased risk of morbidity and mortality after orthotopic liver transplantation, Fenton et al. ${ }^{120}$ studied the clinical, histological, and genetic findings in a series of 7 adult patients with marked iron accumulation in their liver explants and HF despite the absence of HFE mutations. They found that liver explants showed marked iron accumulation predominately involving hepatocytes, with more than $90 \%$ of the stored iron. Thus, Fenton et al. ${ }^{120}$ identified a unique group of liver transplant patients with marked iron deposition in their cirrhotic liver who developed severe cardiac failure and had iron deposits in the heart, despite the absence of major HFE gene mutations. It has been reported that the prevalence of HFE mutations in patients with alcoholic liver disease in northwestern Poland is similar to the healthy populations and other European countries. ${ }^{121}$ Iron overload is potentially amenable to reversal following liver transplantation; however, this may not occur immediately. Susceptibility to infection in the early posttransplant period in patients after liver transplantation 
with iron overload speaks in favor of this hypothesis. In addition, Chow et al. ${ }^{122}$ reported that serum measurements of ferritin, corresponding to the increased levels of serum iron, were independently associated with an increased risk of any infections and death in liver transplant recipients. Similar results were found for the unsaturated iron-binding capacity for the same 2 outcomes. Moreover, Singh and Sun ${ }^{53}$ comprehensively reviewed the potential links between iron overload and unique susceptibility of liver transplant patients to disseminated disease due to opportunistic pathogens. On the other hand, in a small study, Bardet et al. ${ }^{123}$ reported that serum erythropoietin levels were significantly lower after liver transplantation compared with baseline, especially in cyclosporine-treated patients, and were related to hematocrit values in both transplant recipients and control subjects. They also observed a relatively good kidney function and no significant iron deficiency (they assessed only serum ferritin). Bohne et al. ${ }^{124}$ studied the expression of genes involved in the regulation of iron homeostasis and found that operationally tolerant patients exhibited higher serum levels of hepcidin and ferritin and increased hepatocyte iron deposition compared with nontolerant recipients. They also stressed that liver tissue gene expression measurements accurately predicted the outcome of immunosuppressive withdrawal in an independent set of patients. These results pointed to the critical role of iron metabolism in the regulation of intragraft alloimmune responses in humans and provided a set of biomarkers to conduct drug-weaning trials in liver transplantation. On the other hand, as reported by Misra et al., ${ }^{125}$ iron deficiency is a frequent cause of anemia in liver transplant recipients, especially children. In adults, occult gastrointestinal blood loss is frequently recognized as the underlying cause of iron deficiency anemia in colorectal adenoma and carcinoma in liver transplant recipients. ${ }^{126}$ As recommended by Maheshwari et al. ${ }^{127}$ in the "General Guidelines for the Diagnosis of Anemia at Different Intervals Following Liver Transplantation", iron deficiency should be considered in anemic patients over 6 weeks after the procedure.

Why internists should know the mechanism of iron metabolism? Iron deficiency is the most common cause of anemia worldwide, and primary (hemochromatosis) or secondary iron overload is not uncommon either. Moreover, in the vast majority of patients, these conditions are treatable, providing the diagnosis is established early enough. HF, CKD, and anemia are frequent comorbidities, commonly encountered by internists and general practitioners. The awareness that these 3 conditions negatively affect one another leading to exacerbations and clinical deterioration has led to the concept of cardiorenal anemia syndrome. However, the role of iron deficiency within this complex interplay has been less well examined. Iron deficiency frequently occurs in HF with or without anemia ${ }^{92,93}$ and is an independent predictor of death or urgent heart transplantation in $\mathrm{HF}^{95}$ It not only impairs oxygen transport through reduced erythropoiesis, but also adversely affects oxidative metabolism, cellular energetics, immune mechanisms, and the synthesis and degradation of complex molecules such as DNA. In the Ferric Iron Sucrose in Heart Failure (FAIR-HF) trial, intravenous iron therapy resulted in significant improvements in physical functioning in iron-deficient patients with HF, even in nonanemic ones. ${ }^{128}$ Treatment of iron-deficiency anemia frequently involves the identification of the underlying cause, such as occult blood loss from the gastrointestinal tract in adults or nutritional deficiencies in children or the presence of CKD in solid-organ recipients ${ }^{102}$ or even HF. ${ }^{129}$ On the other hand, in patients with end-stage liver disease who are candidates for transplantation, iron overload should also be taken into account. Internists and general practitioners are often the first doctors to take care of organ-transplant recipients, before they present at outpatient transplant clinics or are admitted to hospital transplant units, and in the vast majority the first condition to be suspected or even diagnosed is end-stage organ failure. Therefore, knowledge of iron metabolism would be greatly appreciated among internists for the better care of patients. In addition, due to the links between iron and infection, "pouring oil into the fire", i.e., giving iron during infection, is not recommended. Iron status check-up should be a part of long-term follow-up of renal and nonrenal solid-organ transplant recipients because disturbances in iron metabolism are a possible risk factor for infections or mortality. 


\section{REFERENCES}

1 Brittenham, GM. Disorders of iron metabolism: iron deficiency and overload. In: Hematology Basic Principles and Practice. 2nd ed. Hoffman R, Ben EJ Jr, Shattil SJ, et al., (eds). Churchill Livingstone, New York; 1995: 481.

2 Bridges KR, Seligman PA. Disorders of iron metabolism. In: Blood: Principles \& Practice of Hematology. Handin RI, Lux E, Stossel TP (eds). Lippincott, United States; 1995: 1-428.

3 Roy CN, Enns CA. Iron homeostasis: new tales from the crypt. Blood. 2000; 96: 4020-4027.

4 Philpott CC. Molecular aspects of iron absorption: Insights into the role of HFE in hemochromatosis. Hepatology. 2002; 35: 993-1001.

5 Beaumont C, Beris P, Beuzard Y, Brugnara C. Disorders of erythropoiesis, erythrocytes and iron metabolism. Forum Service Editore, Genoa, Italy 2009. ISBN 978-88-89620-13-7.

6 Ganz T. Hepcidin, a key regulator of iron metabolism and mediator of anemia of inflammation. Blood. 2003; 102: 783-738.

7 Lin L, Goldberg YP, Ganz T. Competitive regulation of hepcidin mRNA by soluble and cell-associated hemojuvelin. Blood. 2005; 106: 2884-2809.

8 Andriopoulos B Jr, Corradini E, Xia Y, et al. BMP6 is a key endogenous regulator of hepcidin expression and iron metabolism. Nat Genet. 2009; 41 482-487

9 Truksa J, Gelbart T, Peng H, et al. Suppression of the hepcidin-encoding gene Hamp permits iron overload in mice lacking both hemojuvelin and matriptase-2/TMPRSS6. Br J Haematol. 2009; 147: 571-581.

10 Silvestri L, Pagani A, Nai A, et al. The serine protease matriptase-2 (TMPRSS6) inhibits hepcidin activation by cleaving membrane hemojuvelin. Cell Metab. 2008; 8: 502-511.

11 Tanno T, Bhanu NV, Oneal PA, et al. High levels of GDF15 in thalassemia suppress expression of the iron regulatory protein hepcidin. Nat Med. 2007; 13: 1096-1101.

12 Ramirez JM, Schaad 0, Durual S, et al. Growth differentiation facto 15 production is necessary for normal erythroid differentiation and is in creased in refractory anaemia with ring-sideroblasts. Br J Haematol. 2009; 144: $251-262$

13 Lakhal S, Talbot NP, Crosby A, et al. Regulation of growth differentiation factor 15 expression by intracellular iron. Blood. 2009; 113: 1555-1563.

14 Andrews NC. Molecular control of iron metabolism. Best Practice Res Clin Hematol. 2005; 18: 159-169.

15 Finch CA, Huebers H. Perspectives in iron metabolism. N Engl J Med. 1982; 306: 1520-1528.

16 Cook JD. Clinical evaluation of iron deficiency. Semin Hematol. 1982 19: 6-18.

17 Bothwell TH. Overview and mechanisms of iron regulation. Nutr Rev. 1995: 53: 237-245.

18 Worwood M. Overview of iron metabolism at a molecular level. J Intern Med. 1989; 226: 381-391.

19 Deaglio S, Capobianco A, Cali A, et al. Structural, functional, and tis sue distribution analysis of human transferrin receptor-2 by murine monoclonal antibodies and a polyclonal antiserum. Blood. 2002; 100: 3782-3789.

20 Robb, A, Wessling-Resnick, M. Regulation of transferrin receptor 2 protein levels by transferrin. Blood. 2004; 104: 4294-4299.

21 Kawabata $\mathrm{H}$, Nakamaki $\mathrm{T}$, Ikonomi $\mathrm{P}$, et al. Expression of transferrin receptor 2 in normal and neoplastic hematopoietic cells. Blood. 2001; 98 2714-2719

22 Johnson MB, Enns CA. Diferric transferrin regulates transferrin receptor 2 protein stability. Blood. 2004; 104: 4287-4293.

23 Finch CA, Bellotti V, Stray S. Plasma ferritin determination as a diag nostic tool. West J Med. 1986; 145: 657-663.

24 Cook JD, Boy E, Flowers $\mathrm{CH}$, Skikne BS. The quantitative assessment of body iron. Blood. 2003; 101: 3359-3363.

25 Fernández-Rodríguez AM, Guindeo-Casasús MC, Molero-Labarta T, et al. Diagnosis of iron deficiency in chronic renal failure. Am J Kidney Dis. 1999; 34: 508-513.

26 Jensen PD. Evaluation of iron overload. Br J Haematol. 2004; 124 $697-711$

27 Edwards CQ, Kushner JP. Screening for hemochromatosis. N En J Med. 1993; 328: 1616-1620.

28 Pippard MJ. Detection of iron overload. Lancet. 1997; 349: 73-74.

29 Milman N. Iron status markers in hereditary haemochromatosis: distinction between individuals being homozygous and heterozygous fo the haemochromatosis allele. Eur J Haematol. 1991; 47: 292-298.

30 Aisen $\mathrm{P}$, Enns C, Wessling-Resnick M. Chemistry and biology of eukaryotic iron metabolism. Int J Biochem Cell Biol. 2001; 33: 940-959.

31 Dey R, Datta SC. Leishmanial glycosomes contain superoxide dis mutase. Biochem J. 1994; 301: 317-319.

32 Zhang $Y$, Lathigra R, Garbe $T$, et al. Genetic analysis of superox ide dismutase, the 23 kilodalton antigen of Mycobacterium tuberculosis. Mol Microbiol. 1991; 5: 381-391.
33 Singh PK, Parsek MR, Greenberg EP, Welsh MJ. A component of innate immunity prevents bacterial biofilm development. Nature. 2002; 417 $552-555$

34 Risso A. Leukocyte antimicrobial peptides: multifunctional effector molecules of innate immunity. J Leukoc Biol. 2000; 68: 785-792.

35 Nemeth E, Valore EV, Territo $\mathrm{M}$, et al. Hepcidin, a putative mediato of anemia of inflammation, is a type II acute-phase protein. Blood. 2003 101: 2461-2463

36 Yang D, Biragyn A, Hoover DM, et al. Multiple roles of antimicrobia defensins, cathelicidins, and eosinophil-derived neurotoxin in host defense. Annu Rev Immunol. 2004; 22: 181-215.

37 Ganz T. Hepcidin, a key regulator of iron metabolism and mediator of anemia of inflammation. Blood. 2003; 102: 783-788.

38 Weinstein DA, Roy CN, Fleming MD, et al. Inappropriate expression of hepcidin is associated with iron refractory anemia: implications for the anemia of chronic disease. Blood. 2002; 100: 3776-3781.

39 Al Younes HM, Rudel T, Brinkmann V, et al. Low iron availability mod ulates the course of Chlamydia pneumoniae infection. Cell Microbiol. 2001 3: 427-437

40 Schaible UE, Collins HL, Priem F, Kaufmann SH. Correction of the iron overload defect in beta-2-microglobulin knockout mice by lactoferrin abolishes their increased susceptibility to tuberculosis. J Exp Med. 2002; 196 1507-1513.

41 Weinberg ED. Iron loading and disease surveillance. Emerg Infect Dis. 1999; 5: 346-352.

42 Muñoz $P$, Fernández NS, Fariñas MC. Epidemiology and risk factors of infections after solid organ transplantation. Enferm Infecc Microbiol Clin. 2012; 30 Suppl 2: 10-18.

3 Pacholczyk M, Lagiewska B, Lisik W, et al. Invasive fungal infections following liver transplantation - risk factors, incidence and outcome. Ann Transplant. 2011; 16: 14-16.

44 Cervera $\mathrm{C}$, Fernández-Ruiz $\mathrm{M}$, Valledor $\mathrm{A}$, et al. Epidemiology and risk factors for late infection in solid organ transplant recipients. Transpl Infect Dis. 2011; 13: 598-607.

45 Alexander J, Limaye AP, Ko CW, et al. Association of hepatic iron overload with invasive fungal infection in liver transplant recipients. Liver Transpl. 2006; 12: 1799-1804.

46 Theurl I, Fritsche G, Ludwiczek S, et al. The macrophage: a cellular factory at the interphase between iron and immunity for the control of infections. Biometals. 2005; 18: 359-367.

47 Schrettl M, Bignell E, Kragl C, et al. Siderophore biosynthesis but no reductive iron assimilation is essential for Aspergillus fumigatus virulence. J Exp Med. 2004; 200: 1213-1219.

48 Oexle $\mathrm{H}$, Kaser A, Most $\mathrm{J}$, et al. Pathways for the regulation of inter feron-gamma-inducible genes by iron in human monocytic cells. J Leukoc Biol. 2003; 74: 287-294.

49 van Asbeck BS, Marx JJ, Struyvenberg A, et al. Effect of iron (III) in the presence of various ligands on the phagocytic and metabolic activity of human polymorphonuclear leukocytes. J Immunol. 1984; 132: 851-856.

50 Weiss G, Umlauft F, Urbanek $M$, et al. Associations between cellula immune effector function, iron metabolism, and disease activity in patient with chronic hepatitis C virus infection. J Infect Dis. 1999; 180: 1452-1458. 51 Schaible U, Kaufmann S. Iron and microbial infection. Nat Rev Microbiol. 2004; 4: 946-953.

52 Patruta SI, Edlinger R, Sunder-Plassmann G, Hörl WH. Neutrophil impairment associated with iron therapy in hemodialysis patients with functional iron deficiency. J Am Soc Nephrol. 1998; 9: 655-663.

53 Singh N, Sun HY. Iron overload and unique susceptibility of liver transplant recipients to disseminated disease due to opportunistic pathogens. Liver Transpl. 2008; 14: 1249-1255.

54 Ashrafian $\mathrm{H}$. Hepcidin: the missing link between hemochromatosis and infections. Infec Immun. 2003; 71: 6693-6700.

55 Davis JW, Sizemore RK. Incidence of Vibrio species associated with blue crabs (Callinectes sapidus) collected from Galveston Bay, Texas. App Environ Microbiol. 1982; 43: 1092-1097.

56 Tamplin M, Rodrick GE, Blake NJ, Cuba T. Isolation and characterisation of Vibrio vulnificus from two Florida estuaries. Appl Environ Microbiol. 1992; 44: 1466-1470.

57 Strom MS, Paranjpye RN. Epidemiology and pathogenesis of Vibrio vulnificus. Microbes Infect. 2000; 2: 177-188.

58 Levine WC, Griffin PM. Vibrio infections on the Gulf Coast: results from first regional surveillance. Gulf Coast Vibrio Working Group. J Infect Dis. 1993; 167: 479-483.

59 Skaar EP, Humayun M, Bae T, et al. Iron-source preference of Staphylococcus aureus infections. Science. 2004; 305: 1626-1628.

60 Rouault TA. Pathogenic bacteria prefer heme. Science. 2004; 305 1577-1578.

61 Eisendle $\mathrm{M}$, Oberegger $\mathrm{H}$, Zadra I, Haas $\mathrm{H}$. The siderophore system is essential for viability of Aspergillus nidulans: functional analysis of two genes encoding l-ornithine N5-monooxygenase (sidA) and a non-ribosomal peptide synthetase (sidC). Mol Microbiol. 2003; 49: 359-375. 
62 Boelaert JR, de Locht M, Van Cutsem J, et al. Mucormycosis during deferoxamine therapy is a siderophore-mediated infection. In vitro and in vivo animal studies. J Clin Invest. 1993; 91: 1979-1986.

63 Howard DH. Acquisition, transport, and storage of iron by pathogenic fungi. Clin Microbiol Rev. 1999; 12: 394-404

64 Crowe WE, Maglova LM, Ponka P, Russell JM. Human cytomegalovirus-induced host cell enlargement is iron dependent. Am J Physiol Cell Physiol. 2004; 287: C1023-C1030.

65 Romeo AM, Christen L, Niles EG, Kosman DJ. Intracellular chelation of iron by bipyridyl inhibits DNA virus replication: ribonucleotide reductas maturation as a probe of intracellular iron pools. J Biol Chem. 2001; 276: 24301-24308.

66 van Asbeck BS, Georgiou NA, van der Bruggen T, et al. Anti-HIV effect of iron chelators: different mechanisms involved. J Clin Virol. 2001; 20: 141-147.

67 Kartikasari AE, Georgiou NA, de Geest M, et al. Iron enhances endothelial cell activation in response to Cytomegalovirus or Chlamydia pneumoniae infection. Eur J Clin Invest. 2006; 36: 743-752.

68 Haririan A, Morawski K, West MS, et al. Sirolimus exposure during the early post-transplant period reduces the risk of CMV infection relative to tacrolimus in renal allograft recipients. Clin Transplant. 2007; 21: 466-471.

69 Marty F, Bryar J, Browne S, et al. Sirolimus-based graft-versus-hos disease prophylaxis protects against cytomegalovirus reactivation after a logeneic hematopoietic stem cell transplantation: a cohort analysis. Blood. 2007; 110: 490-500.

70 Ammendolia M, Marchetti M, Superti F. Bovine lactoferrin prevent the entry and intercellular spread of herpes simplex virus type 1 in Green Monley Kidney cells. Antivir Res. 2007; 76: 252-262.

71 Farigon S, Fracabzani AL, Sampietro $M$, et al. Liver iron influences the response to interferon alpha therapy in chronic hepatitis C Eur J Gastroenterol Hepatol. 1997; 9: 497-503.

72 Piperno A, Sampietro M, D'Alba R, et al. Iron stores, response to alpha-interferon therapy, and effects of iron depletion in chronic hepatitis C. Liver. 1996; 16: 248-254.

73 Kulaksiz H, Gehrke SG, Janetzko A, et al. Pro-hepcidin: expression and cell specific localisation in the liver and its regulation in hereditary haemo chromatosis, chronic renal insufficiency, and renal anaemia. Gut. 2004; 53 735-743

74 Malyszko J, Malyszko JS, Koc-Zorawska E, et al. Neutrophil gelatinase-associated lipocalin in dialyzed patients is related to residual renal function, type of renal replacement therapy and inflammation. Kidney Blood Press Res. 2009; 32: 464-469.

75 Malyszko J, Malyszko JS, Kozminski P, et al. Possible relationship between neutrophil gelatinase-associated lipocalin, hepcidin, and inflammation in haemodialysed patients. Nephron Clin Pract. 2010; 115: c268-c275.

76 Mix TC, Kazmi W, Khan S, et al. Anemia: a continuing problem following kidney transplantation. Am J Transplant. 2003; 3: 1426-1433.

77 Yorgin PD, Scandling JD, Belson A, et al. Late post-transplant anemia in adult renal transplant recipients. An under-recognized problem? Am J Transplant. 2002; 2: 429-435.

78 Moore J, He X, Cockwell P, et al. The impact of hemoglobin levels on patient and graft survival in renal transplant recipients. Transplantation. 2008; 86: 564-570.

79 Shibagaki Y Shetty A. Anemia is common after kidney transplantation, especially among African Americans. Nephrol Dial Transplant. 2004; 19: 2368-2373.

80 Lorenz M, Kletzmayr J, Perschl A, et al. Anemia and iron deficiencie among long-term renal transplant recipients. J Am Soc Nephrol. 2002; 13 794-797.

81 Shah N, Al-Khoury S, Afzali B, et al. Posttransplantation anemia in adult renal allograft recipients: prevalence and predictors. Transplantation. 2006 810: $1112-1118$

82 Zheng $\mathrm{S}$, Coyne DW, Joist $\mathrm{H}$, et al. Iron deficiency anemia and iron losses after renal transplantation. Transpl Int. 2009; 22: 434-440.

83 Jimeno L, Rodado R, Campos M, Lanuza M. Iron deficiency - an underrecognized problem in nonanemic and erythrocytic kidney transplant recipients: risks and effects of ACEl and of iron treatment. Transplant Proc. 2005; 37: 1007-1008.

84 Przybylowski P, Malyszko J, Glowinska I, et al. Prevalence of iron de ficiency in heart and kidney allograft recipients. Transplant Proc. 2011; 43 3885-3887.

85 Mudge DW, Tan KS, Miles R, et al. A randomized controlled trial of intravenous or oral iron for posttransplant anemia in kidney transplantation. Transplantation. 2012; 93: 822-826.

86 Breuer W, Hershko $C$, Cabantchik ZI. The importance of non-transferrin iron in disorders of iron metabolism. Transfusion Sci. 2000; 23: 185-192.

87 Salonen JT, Nyyssönen K, Korpela H, et al. High stored iron levels are associated with excess risk of myocardial infarction in eastern Finnish men. Circulation. 1992; 86: 803-811.

88 Tielemans $\mathrm{CL}$, Lenclud $\mathrm{CM}$, Wens $\mathrm{R}$, et al. Critical role of iron overload in the increased susceptibility of haemodialysis patients to bacterial infec- tions. Beneficial effects of desferrioxamine. Nephrol Dial Transplant. 1989; 4: 883-887

89 Espósito BP, Breuer W, Slotki I, Cabantchik ZI. Labile iron in parenteral iron formulations and its potential for generating plasma nontransferrin-bound iron in dialysis patients. Eur J Clin Invest. 2002; 32 Suppl 1 : $42-49$

90 Malyszko J, Glowinska I, Malyszko JS, et al. Iron metabolism in kidne allograft recipients: still a mystery? Transplant Proc. 2011; 43: 2973-2975.

91 Collins AJ, Li S, Gilbertson DT, et al. Chronic kidney disease and cardiovascular disease in the Medicare population. Kidney Int Suppl. 2003; 87: S24-S31.

92 Parikh A, Natarajan S, Lipsitz SR, Katz SD. Iron deficiency in community-dwelling US adults with self-reported heart failure in the National Health and Nutrition Examination Survey III: prevalence and associations with anemia and inflammation. Circ Heart Fail. 2011; 4: 599-606.

93 Okonko DO, Mandal AK, Missouris CG, Poole-Wilson PA. Disordered iron homeostasis in chronic heart failure: prevalence, predictors, and relation to anemia, exercise capacity, and survival. J Am Coll Cardiol. 2011; 58: $1241-1251$.

94 Macdougall IC, Canaud B, de Francisco AL, et al. Beyond the cardio renal anaemia syndrome: recognizing the role of iron deficiency. Eur $\mathrm{J}$ Heart Fail. 2012; 14: 882-886

95 Jankowska EA, Rozentryt $P$, Witkowska A, et al. Iron deficiency: an om inous sign in patients with systolic chronic heart failure. Eur Heart J. 2010; 31: $1872-1880$.

96 Przybylowski P, Malyszko J, Malyszko JS, et al. Anemia in heart and kidney allograft recipients: is there a role for hepcidin? Transplant Proc 2010; 42: 4255-4258.

97 Przybylowski P, Malyszko JS, Macdougall IC, et al. Iron metabolism, hepcidin and anemia in orthotopic heart transplantation treated with mTOR. Transplant Proc. 2012. In press.

98 Maiorano A, Stallone G, Schena A, et al. Sirolimus interferes with iron homeostasis in renal transplant recipients. Transplantation. 2006; 82 908-912.

99 McDonald MA, Gustafsson F, Almasood A, et al. Sirolimus is associated with impaired hematopoiesis in heart transplant patients? A retrospective analysis. Transplant Proc. 2010; 42: 2693-2696.

100 Müller HM, Horina JH, Kniepeiss D, et al. Characteristics and clinical relevance of chronic anemia in adult heart transplant recipients. Clin Transplant. 2001; 15: 343-348.

101 Przybylowski P, Malyszko J, Levin-laina N, Malyszko JS. Lack of non-transferrin-bound iron in heart transplant recipients. Transplant Proc. 2011: 43: 3068-3070.

102 Przybylowski P, Koc-Zorawska E, Glowinska I, et al. Hemojuvelin and iron metabolism in kidney and heart allograft recipients. Transplant Proc. 2012. In press.

103 Przybylowski P, Malyszko J, Malyszko JS. A possible role of hepcidin in the pathogenesis of anemia in heart allograft recipients. Transplant Proc 2010; 42: 1803-1807.

$104 \mathrm{Ojo} \mathrm{AO}$, Held PJ, Port FK, et al. Chronic renal failure after transplantation of a nonrenal organ. N Eng J Med. 2003; 349: 931-940.

105 Fisher NC, Nightingale PG, Gunson BK, et al. Chronic renal failure following liver transplantation: a retrospective analysis. Transplantation. 1998, 66: $59-66$.

106 A comparison of tacrolimus (FK 506) and cyclosporine for immunosuppression in liver transplantation. The U.S. Multicenter FK506 Liver Study Group. N Eng J Med. 1994; 331: 1110-1115.

107 Gonwa TA, Mai ML, Melton LB, et al. End-stage renal disease (ESRD) after orthotopic liver transplantation (OLTX) using calcineurin-based immunotherapy: risk of development and treatment. Transplantation. 2001; 72 1934-1939.

108 Malyszko J, Durlik M, Przybylowski P. Kidney dysfunction after non renal solid organ transplantation. Ann Transplant. 2009; 14: 71-79.

109 Fikatas P, Ulrich F, Lee JE et al. The APACHE III score as preoperative indicator of patient outcome in liver transplantation after fulminant hepatic failure. Ann Transplant. 2011; 16: 18-25

110 Babitt JL, Huang FW, Wrighting DM, et al. Bone morphogenetic protein signaling by hemojuvelin regulates hepcidin expression. Nat Genet 2006; 38: 531-539.

111 Andriopoulos B Jr, Corradini E, Xia Y, et al. BMP6 is a key endogenous regulator of hepcidin expression and iron metabolism. Nat Genet. 2009 41: 482-487.

112 Meynard D, Kautz L, Darnaud V, et al. Lack of the bone morphoge netic protein BMP6 induces massive iron overload. Nat Genet. 2009; 41 478-481.

113 Papanikolaou G, Samuels ME, Ludwig EH, et al. Mutations in HFE2 cause iron overload in chromosome 1q-linked juvenile hemochromatosis. Nat Genet. 2004; 36: 77-82.

114 Kautz L, Meynard D, Monnier A, et al. Iron regulates phosphorylation of Smad1/5/8 and gene expression of Bmp6, Smad7, Id1, and Atoh8 in the mouse liver. Blood. 2008; 112: 1503-1509. 
115 Zhang AS, Anderson SA, Wang J, et al. Suppression of hepatic hepcidin expression in response to acute iron deprivation is associated with an in crease of matriptase-2 protein. Blood. 2011; 117: 1687-1699.

116 Tung BY, Farrell FJ, McCashland TM, et al. Long-term follow-up af ter liver transplantation in patients with hepatic iron overload. Liver Trans pl. 1999; 5: 369-374.

117 Keeffe EB. Liver transplantation in patients with hepatic iron overload: favorable or unfavorable outcome? Hepatology. 2000; 32: 1396-1398.

118 Singh N, Wannstedt C, Keyes L, et al. Hepatic iron content and the risk of Staphylococcus aureus bacteremia in liver transplant recipients. Prog Transplant. 2007; 17: 332-336.

119 O'Glasser AY, Scott DL, Corless CL et al. Hepatic and cardiac iron overload among patients with end-stage liver disease referred for liver transplantation. Clin Transplant. 2010; 24: 643-651.

120 Fenton $\mathrm{H}$, Torbenson M, Vivekanandan P, et al. Marked iron in liver explants in the absence of major hereditary hemochromatosis gene defects: a risk factor for cardiac failure. Transplantation. 2009; 87: 1256-1260.

121 Raszeja-Wyszomirska J, Kurzawski G, Zawada I, et al. HFE gene mutations in patients with alcoholic liver disease. A prospective study from northwestern Poland. Pol Arch Med Wewn. 2010; 120: 127-131.

122 Chow JK, Werner BG, Ruthazer R, Snydman DR. Increased serum iron levels and infectious complications after liver transplantation. Clin Infect Dis. 2010; 51: e16-23.

123 Bardet $\mathrm{V}$, Junior $\mathrm{AP}$, Coste $\mathrm{J}$, et al. Impaired erythropoietin production in liver transplant recipients: the role of calcineurin inhibitors. Liver Transpl. 2006; 12: 1649-1654.

124 Bohne F, Martínez-Llordella M, Lozano JJ, et al. Intra-graft expression of genes involved in iron homeostasis predicts the development of operational tolerance in human liver transplantation. J Clin Invest. 2012; 122 368-382.

125 Misra S, Moore TB, Ament ME, et al. Profile of anemia in children after liver transplantation. Transplantation. 2000; 70: 1459-1463.

126 Atassi T, Thuluvath PJ. Risk of colorectal adenoma in liver transplant recipients compared to immunocompetent control population undergoing routine screening colonoscopy. J Clin Gastroenterol. 2003; 37: 72-73.

127 Maheshwari A, Mishra R, Thuluvath PJ. Post-liver-transplant anemia: etiology and management. Liver Transpl. 2004; 10: 165-173.

128 Anker SD, Comin Colet J, Filippatos G, et al. FAIR-HF Trial Investigators. Ferric carboxymaltose in patients with heart failure and iron deficiency. N Eng J Med. 2009; 361: 2436-2448.

129 Kaldara-Papatheodorou EE, Terrovitis JV, Nanas JN. Anemia in heart failure: should we supplement iron in patients with chronic heart failure? Pol Arch Med Wewn. 2010; 120: 354-360. 


\title{
Metabolizm żelaza u pacjentów po transplantacji narządów unaczynionych - jak daleko jesteśmy jeszcze od rozwiązania tajemnicy?
}

\author{
Jolanta Małyszko', Nomy Levin-Iaina², Michał Myśliwiec', \\ Piotr Przybyłowski ${ }^{3}$, Magdalena Durlik ${ }^{4}$ \\ 1 Klinika Nefrologii i Transplantologii, Uniwersytet Medyczny, Białystok \\ 2 Nephrology and Hypertension Institute, Chaim Sheba Medical Center, Tel-Hashomer Hospital, Ramat Aviv, Izrael \\ 3 Klinika Kardiochirurgii i Transplantacji, Uniwersytet Jagielloński, Collegium Medicum, Kraków \\ 4 Klinika Nefrologii i Medycyny Transplantacyjnej, Warszawski Uniwersytet Medyczny, Warszawa
}

\section{SŁOWA KLUCZOWE}

ferrytyna, hepcydyna, metabolizm żelaza, transplantacja wątroba, serce
Adres do korespondencji:

prof. dr hab. med. Jolanta Małyszko, Klinika Nefrologii i Transplantologii, Uniwersytet Medyczny,

ul. Żurawia 14, 15-540 Białystok, tel.: 85-740-94-64, fax: 85-743-45-86, e-mail: jolmal@poczta.onet.pl Praca wpłynęła: 10.09.2012. Przyjęta do druku: 04.10.2012. Nie zgłoszono sprzeczności interesów.

Pol Arch Med Wewn. 2012; 122 (10): 504-511

Copyright by Medycyna Praktyczna, Kraków 2012

\section{STRESZCZENIE}

Żelazo jest najczęstszym metalem przejściowym w organizmie ludzkim niezbędnym do wzrostu i przetrwania organizmów. Nasze zrozumienie znaczenia molekularnej kontroli metabolizmu żelaza wzrosło istotnie w ciągu ostatnich 10 lat dzięki odkryciu hepcydyny, która odpowiada za regulację wchłaniania żelaza w przewodzie pokarmowym oraz jego mobilizację z makrofagów i depozytów w wątrobie. Mimo że interniści i lekarze podstawowej opieki zdrowotnej bardzo często stykają się zarówno z przypadkami niedoboru żelaza, jak i niedokrwistości, bardzo niewiele wiemy o metabolizmie żelaza u pacjentów po przeszczepieniu narządów unaczynionych. W tej pracy poglądowej podsumowano dotychczasową wiedzę o metabolizmie żelaza po transplantacji serca, nerek i wątroby. Często obserwuje się zarówno niedobór i/lub niedokrwistość, jak i przeładowanie żelazem, jednak mechanizmy tych zaburzeń nie są dobrze poznane. Niedobór żelaza występuje częściej u biorców przeszczepu nerki czy serca, zaś nadmiar żelaza - u biorców wątroby. Należy wziąć pod uwagę wtórne i potencjalnie odwracalne przyczyny tych zaburzeń, jak np. stan zapalny, upośledzona funkcja graftu czy rodzaj leczenia immunosupresyjnego. Ponadto ocena metabolizmu żelaza powinna być badaniem rutynowym $w$ długoterminowym leczeniu chorych, gdyż zaburzenia tego metabolizmu są czynnikiem ryzyka infekcji i śmiertelności w populacji biorców. Ponieważ interniści i specjaliści medycyny rodzinnej są często pierwszymi lekarzami zajmującymi się pacjentami po transplantacji (zanim dotrą oni do poradni czy oddziatów specjalistycznych), wiedza o podstawowych zaburzeniach metabolizmu żelaza w tej wyjątkowej populacji może być przydatna w diagnozowaniu i leczeniu tych chorych - zarówno jako kandydatów do transplantacji, jak i w okresie po przeszczepieniu narządów unaczynionych. 